\title{
Pengaruh Strategi Analogi Terhadap Pemahaman Konsep Materi Cahaya pada Siswa Kelas VIII SMP Negeri 8 Palu
}

\author{
Fadhillah, Darsikin, dan Muslimin \\ Ilafadila3@gmail.com \\ Program Studi Pendidikan Fisika FKIP Universitas Tadulako \\ Jl. Soekarno Hatta Km. 9 Kampus Bumi Tadulako Tondo Palu - Sulawesi Tengah
}

\begin{abstract}
Abstrak - Penelitian ini bertujuan untuk mengetahui pengaruh strategi analogi terhadap pemahaman konsep materi cahaya pada siswa kelas viii SMP N 8 Palu. Jenis penelitian ini merupakan eksperimen kuasi dengan desain equivalent pretest-posttest. Populasi penelitian adalah siswa kelas VIII SMP Negeri 8 Palu. Teknik Sampling yang digunakan adalah purposive sampling dengan sampel penelitian adalah kelas VIII A sebagai kelompok eksperimen dan kelas VIII B sebagai kelompok kontrol. Instrumen yang digunakan adalah tes pemahaman konsep fisika yang telah divalidasi oleh ahli. Hasil tes pemahaman konsep fisika yang menunjukkan bahwa skor rata-rata kelompok eksperimen 14,20 lebih tinggi dari kelas kontrol yaitu 11,85. Uji hipotesis uji $t$ (dua pihak), diperoleh $t_{\text {hitung }}=3,11$ dan $t_{\text {tabel(0.975)(38) }}=2,04$ pada taraf nyata $a=0,05$. Ini berarti bahwa nilai $t_{\text {hitung }}$ berada di luar daerah penerimaan Ho. Dengan demikian dapat disimpulkan bahwa ada perbedaan pemahaman konsep fisika antara kedua kelas yang menggunakan strategi analogi dan kelas yang menggunakan model konvensional. Tingginya skor tes pemahaman konsep fisika siswa kelas eksperimen, disebabkan karena kelas ekperimen menggunakan strategi analogi, sehingga siswa berperan aktif dalam proses pembelajaran dan secara kreatif menemukan permasalahan yang diajukan.
\end{abstract}

Kata Kunci : Strategi Analogi, Pemahaman Konsep Fisika

\section{PENDAHULUAN}

Fisika merupakan ilmu pengetahuan sains yang mempelajari tentang hukum-hukum alam dan aplikasi dalam kehidupan. Konsep fisika ada yang abstrak, ada yang konkret. Hal ini yang membuat siswa beranggapan fisika sulit dimengerti dan membosankan, kecuali jika di kaitkan dengan pengalaman seharihari. Ceramah menjadi pilihan utama strategi belajar bagi guru dalam menjalankan proses belajar mengajar. Sehingga menjadikan siswa jenuh dan tidak adanya motivasi dalam belajar di kelas. Proses belajar mengajar inilah yang berlangsung terus menerus dalam sistem pembelajaran yang pada akhirnya menjadikan hasil belajar siswa yang tidak memuaskan.

Setiap belajar fisika, dalam benak siswa yang akan dipelajari adalah rumus-rumus rumit serta hitungan sulit yang dapat memusingkan kepala. Hal ini sering menjadi penyebab yang selalu menghantui setiap siswa pada pelajaran fisika. Akhirnya itu berdampak besar bagi hasil belajar siswa. Dampak dari permasalahan-permasalahan tersebut terjadi pada hampir semua materi fisika, salah satunya pada materi cahaya. Pada materi ini pembelajaran terkadang bersifat teoritis. Cara guru menyajikan materi pembelajaran kadang membosankan sehingga tidak jarang siswa bingung dan sulit memahami materi yang diberikan. Untuk memahami fisika yang lebih nyata, maka guru fisika dalam pembelajaran dapat mengunakan strategi analogi pada saat berkomunikasi dengan siswa untuk menyampaikan konsepkonsep fisika yang berada diluar jangkauan persepsi indera. Dengan strategi analogi para guru membantu siswa membangun pengertian-pengertian, konsep-konsep baru yang dianggap rumit dan abstrak dari konsep yang telah diketahui dengan baik.

Strategi pembelajaran analogi adalah strategi penjelasan suatu konsep dengan cara menganalogikan dengan suatu peristiwa yang mudah dimengerti oleh siswa [1]. Guru fisika dapat menjelaskan konsep sulit dan abstrak melalui strategi ini. Proses berpikir siswa diarahkan dengan analogi yang sesuai dengan pokok bahasan untuk membentuk konsep, bernalar, berpikirkritis, membuat keputusan, berpikir kreatif dan memecahkan berbagai soal dalam fisika. Kehadiran analogi mutlak diperlukan, khususnya jika materi ajar berhubungan dengan wilayah di luar jangkauan panca indera manusia atau alat bantu visual untuk pengamatan [2]. Strategi analogi dapat berperan sebagai salah satu strategi dalam berbagai pokok bahasan fisika. Strategi ini dapat digunakan sebagai suatu strategi alternative untuk memecahkan kebuntuan komunikasi belajar antara guru dan siswa. Dengan menggunakan strategi analogi, pengayaan materi ajar tidak saja dapat 
dilakukan melalui latihan soal berulang dan berjenjang, melainkan juga dapat dengan mem

perkenalkan paradigma baru agar diperoleh spektrum pemahaman materi ajar yang lebih luas dan komprehensif

Berdasarkan dengan pemaparan di atas, maka dilakukan penelitian tentang pengaruh strategi analogi terhadap pemahaman konsep materi cahaya pada siswa kelas VIII SMP N 8 Palu.

\section{METODE PENELITIAN}

Desain atau rancangan penelitian ini menggunakan "ekivalen pretest-posttest design" atau rancangan pretest-posttest yang ekuivalen. Bentuk desainnya disajikan pada Tabel 1 [3]

TABEL 1 DESAIN PENELITIAN

\begin{tabular}{|c|c|c|c|}
\hline Group & $\begin{array}{l}\text { Tes } \\
\text { Awal }\end{array}$ & Perlakuan & $\begin{array}{l}\text { Tes } \\
\text { Akhir }\end{array}$ \\
\hline $\begin{array}{c}\text { Kelas } \\
\text { Eksperimen }\end{array}$ & $\mathrm{O}_{1}$ & $X$ & $\mathrm{O}_{1}$ \\
\hline Kelas Kontrol & $\mathrm{O}_{1}$ & - & $\mathrm{O}_{1}$ \\
\hline
\end{tabular}

Keterangan :

$\mathrm{O}_{1}$ : Tes awal (pretest) dan tes akhir (posttest)

$X$ : Perlakuan untuk kelompok eksperimen dengan menggunakan strategi analogi.

Populasi dalam penelitian ini adalah seluruh siswa kelas VIII SMP Negeri 8 Palu Tahun ajaran 2016/2017 yang terdiri dari 4 kelas. Penarikan sampel pada penelitian ini ditentukan dengan menggunakan tekhnik purposive sampling atau "penentuan sampel dengan pertimbangan tertentu".

Dua kelas yang dijadikan tempat penelitian ini adalah kelas yang diajar oleh guru yang sama, yaitu kelas VIII A diberikan model pembelajaran dengan strategi analogi (kelas eksperimen) dan kelas VIII B menggunakan model konvensional (kelas kontrol).

Instrumen yang digunakan penelitian ini berupa tes pemahaman konsep. Tes ini dibuat dalam bentuk tes esai sebanyak 5 item. Proses analisis tes dilakukan melalui validitas ahli yang ditekankan pada validitas isi dan validitas konstruksi

\section{HASIL DAN PEMBAHASAN}

Posttest (tes akhir) digunakan untuk mengetahui kemampuan akhir siswa setelah mengikuti pembelajaran dengan menggunakan strategi analogi. Data posttest terdiri dari kelas eksperimen dan kelas kontrol yang masing- masing berjumlah 20 siswa. Berdasarkan hasil pemberian posttest diperoleh skor minimum siswa kelas eksperimen adalah 10 dan skor maksimum adalah 18. Sedangkan untuk kelas kontrol skor minimum yang diperoleh siswa adalah 8 dan skor maksimumnya adalah 17 . Adapun data hasil penelitian di atas, disajikan pada Tabel 2.

\begin{tabular}{lcccc}
\hline \multirow{1}{*}{ Uraian } & \multicolumn{2}{c}{ Kelas Kontrol } & \multicolumn{2}{c}{ Kelas Eksperimen } \\
\cline { 2 - 5 } & Tes awal & Tes akhir & Tes awal & Tes akhir \\
\hline Jumlah siswa & 20 & 20 & 20 & 20 \\
Skor Minimum & 3 & 8 & 4 & 10 \\
Skor Maksimum & 11 & 17 & 12 & 18 \\
Skor Rata-rata & 6,35 & 11,85 & 7,7 & 14,2 \\
Standar Deviasi & 2,73 & 2,70 & 2,83 & 2,70 \\
\hline
\end{tabular}

TABEL 2 DESKRIPSI SKOR TES PEMAHAMAN KONSEP FISIKA SISWA UNTUK KELAS EKSPERIMEN DAN KELAS KONTROL

Uji normalitas pada penelitian ini menggunakan uji Chi-kuadrat dengan kriteria penerimaan $X^{2}$ Hitung $<X^{2}$ tabel, taraf signifikansi a $=0,05$ dan derajat kebebasan $\mathrm{dk}=\mathrm{k}-3$. Berdasarkan hasil perhitungan posttest, nilai $\chi^{2}$ hitung untuk ke las eksperimen adalah sebesar 4,00 dan kelas kontrol sebesar 1,49 dengan $\chi^{2}$ tabel sebesar 5,99. Dari data tersebut, diketahui nilai $X^{2}$ Hitung $<X^{2}$ tabel sehingga dapat disimpulkan nilai posttest berasal dari populasi yang terdistribusi normal.

Uji homogenitas pada penelitian ini menggunakan uji statistik $F$ dengan taraf signifikansi $a=0,05$. untuk posttest nilai varians kelas eksperimen sebesar 8,39 serta kelas kontrol sebesar 6,43. Berdasarkan hasil perhitungan, diperoleh nilai $F_{\text {hitung }}$ sebesar 1,30 sedangkan nilai $F_{\text {tabel sebesar 2,12. }}$ Berdasarkan hasil output uji homogenitas dengan taraf signifikansi $(a=0,05)$, dari data tersebut terlihat bahwa Fhitung lebih kecil dari

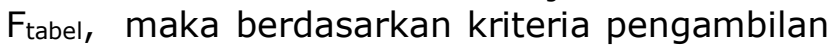
keputusan dapat disimpulkan bahwa tidak terdapat perbedaan varians antara kelas eksperimen dan kelas kontrol atau dengan kata lain varians antara kelas eksperimen dan kelas kontrol adalah sama atau homogen.

Setelah terpenuhinya uji normalitas dan homogenitas, maka dilakukan uji beda ratarata (dua pihak) atau uji t. dimana $\mathrm{H}_{\mathrm{o}}$ diterima jika $-\mathrm{t}_{(1-1 / 2 \alpha)}<\mathrm{t}<\mathrm{t}_{(1-1 / 2 \alpha)}$, Uji hipotesis uji $\mathrm{t}$ (dua pihak) diperoleh thitung $=3,11$ dan tabel(0.975)(38) $=2,04$ pada taraf nyata $a=0,05$. Ini berarti bahwa nilai thitung berada di luar daerah penerimaan Ho. Dengan demikian 
dapat disimpulkan bahwa ada perbedaan pemahaman konsep fisika antara kedua kelas yang menggunakan strategi analogi dan kelas yang menggunakan model konvensional

Diperolehnya hasil tersebut dimungkinkan karena dalam pembelajaran menggunakan strategi analogi, siswa berperan aktif dalam proses pembelajaran dan

secara kreatif berusaha menemukan permasalahan yang diajukan. Pada tes akhir terdapat perbedaan yang cukup signifikan, dengan menggunakan soal pemahaman konsep dalam bentuk essay sebanyak 5 nomor, yang mana tes ini juga telah divalidasi oleh validitas ahli, siswa kelas eksperimen lebih banyak menjawab soal dengan benar dibandingkan dengan siswa di kelas kontrol. Skor rata-rata tes akhir kedua kelas yaitu kelas eksperimen dan kelas kontrol masingmasing memperoleh 14,20 dan 11,85.

Berdasarkan hasil yang perolehan, skor rata-rata kelas eksperimen lebih tinggi dibandingkan kelas kontrol. hasil pemberian posttest ini didukung oleh hasil analisis uji hipotesis (Uji-t) dua pihak. Berdasarkan hasil perhitungan diperoleh nilai thitung $=3,11$ dan $t_{\text {tabel }}=2,04$. Berdasarkan hasil tersebut diketahui nilai thitung $\geq t_{\text {tabel }}$ atau 3,11 $\geq 2,04$, yang artinya hipotesis $H_{1}$ diterima. Dengan kata lain terdapat perbedaan pemahaman konsep fisika antara kedua kelas baik yang menggunakan strategi analogi maupun kelas yang menggunakan model konvensional.

Siswa yang mengikuti pembelajaran dengan strategi analogi lebih menguasai materi yang diajarkan dibandingkan dengan siswa yang mengikuti pembelajaran langsung atau konvensional. Terjadinya perbedaan yang signifikan pada kelas eksperimen ini juga dipengaruhi oleh tingkat pengetahuan siswa dalam menguasai setiap materi fisika. Strategi analogi ini dirasakan peneliti saat melakukan penelitian diantaranya hampir seluruh siswa aktif dalam proses pembelajaran sehingga guru hanya berperan sebagai fasilitator, para siswa juga dapat memahami konsep-konsep fisika yang bersifat abstrak. Pernyataan ini juga didukung oleh penelitian-penelitian sebelumnya diantaranya [4] dalam hasil penelitiannya mengungkapkan, Analogi memainkan peran vital dalam proses pembelajaran sains sekolah melalui pengajaran yang kreatif dan inovatif oleh guru sains, serta pelatihan keterampilan berpikir dan pembentukan kepribadian siswa melalui tindak kritis, logis, dan analitis. kemudian Penelitian yang dilakukan oleh Nurdiana (2013) menyatakan bahwa metode analogi dapat digunakan untuk mengembangkan kreasi dan inovasi pembelajaran sains dalam arti sesungguhnya ${ }^{[5]}$.

Dalam proses pembelajaran dikelas, siswa mengalami kesulitan dalam membedakan sifat-sifat bayangan pada cermin datar, cermin cekung, dan cermin cembung. Sebagian siswa telah dapat menjawab semua soal dengan baik. Walaupun masih terdapat sebagian siswa yang belum mampu menjawab soal dengan tepat. Namun dari hasil tes akhir, dapat dilihat adanya peningkatan pemahaman siswa. Penggunaan Lembar Kerja Siswa (LKS) juga sangat membantu dalam kelancaran kegiatan pembelajaran. Dalam penelitian ini digunakan LKS sebagai penuntun percobaan dan LKS yang berisi soal-soal. Hal ini bertujuan untuk mengarahkan siswa ketika praktek dan membiasakan siswa untuk bekerjasama dalam kelompok. Meskipun demikian peneliti menyadari bahwa tidak sepenuhnya pembelajaran yang dilakukan berjalan dengan sempurna, ada beberapa kendala yang juga menjadi penghambat dalam penelitian ini, diantaranya kurangnya perhatian siswa saat mengikuti proses pembelajaran dikelas. Selain itu, selama proses penelitian masih terdapat siswa yang kurang disiplin dalam mengerjakan tugas yang diberikan.

Berbeda dengan kelas kontrol, model pembelajaran yang diterapkan adalah model pembelajaran konvensional sebagai pembanding kelas eksperimen yang menggunakan strategi analogi, siswa dalam kegiatan pembelajaran konvensional ini lebih banyak berpikir sendiri dan kurang aktif dalam kegiatan pembelajaran. Hal ini juga dapat mempengaruhi pemahaman konsep fisika siswa karena siswa tidak secara aktif dan kreatif dalam proses pembelajaran yang seharusnya siswa lebih banyak berperan.

Kelebihan dari model pembelajaran ini dibandingkan dengan pembelajaran langsung adalah sebagai jembatan psikologi siswa dalam memahami konsep-konsep fisika yang bersifat abstrak, Memvisualisasi konsepkonsep fisika yang abstrak, Menimbulkan rasa ingin tahu dan meningkatkan kreativitas siswa, Mendorong terjadinya belajar bermakna. Selain dari kelebihan tersebut, adapula kekurangan dari model ini yaitu Analogi yang tidak familiar bagi siswa dapat menambah kebimbangan siswa, Kurang efektif untuk siswa yang belum memiliki kemampuan visualisasi berpikir logis dan berpikir rasional, Kurangnya pemetaan ciri-ciri target dan analog dalam analogi yang dibuat oleh guru dapat menyebabkan salah konsep bagi siswa. 


\section{KESIMPULAN DAN SARAN}

Berdasarkan hasil penelitian dan analisis data baik dari hasil preetest, posttest, maupun uji statistik disimpulkan bahwa terdapat pengaruh rata-rata pemahaman konsep fisika antara kelompok siswa yang mengikuti pembelajaran strategi analogi dengan model konvensional pada siswa kelas VIII SMP Negeri 8 Palu. Kriteria penerimaan Ho adalah jika -t $(1-0,5 a)<t<t(1-0,5 a)$. Berdasarkan daftar tabel distribusi $t$ diperoleh harga tabel $=2,04$ sedangkan thitung $=3,11$. Hasil uji hipotesis ini memperlihatkan bahwa harga thitung tidak berada di dalam daerah penerimaan $\mathrm{Ho}$ atau dengan kata lain $\mathrm{H}_{1}$ diterima pada taraf nyata $a=0,05$.

Berdasarkan kesimpulan ada beberapa saran yang dapat dikemukakan: (1) strategi pembelajaran analogi dapat diterapkan sebagai salah satu alternatif dalam pembelajaran fisika. (2) penelitian sejenis dapat dilakukan lagi untuk melihat hasil yang lebih baik dengan materi dan lokasi tempat penelitian yang berbeda. Perbedaan lingkungan dan materi mungkin saja berpengaruh pada pemahaman konsep fisika siswa.

\section{DAFTAR PUSTAKA}

[1] Suparno, P. 2007. Metodologi Pembelajaran Fisika Konstruktivistik dan menyenangkan. Yogyakarta: Universitas Sanata Dharma

[2] Prastowo, T. 2011. Strategi Pengajaran Sains dengan Analogi. Jurnal Penelitian Fisika dan Aplikasinya (JPFA) pada FMIPA, Universitas Negeri Surabaya: diterbitkan

[3] Suharsaputra, U. 2012. Metode Penelitian Kuantitatif, Kualitatif dan Tindakan. Bandung: PT Refika Aditama

[4] Hasanah, D. 2008. Analogi Sebagai Suatu Metode Alternatif Dalam Pengajaran Sains Fisika Sekolah. Jurnal pada Fakultas Sains dan Teknologi, UIN Sunan Kalijaga Yogyakarta: diterbitkan

[5] Nurdiana. 2013. Pengembangan Modul Fisika Berbasis Analogi Konsep Pada Materi Pokok Listrik Statis. Skripsi pada Fakultas Sains dan Teknologi, UIN Sunan Kalijaga Yogyakarta: diterbitkan 